\title{
Regional Institutions in Rural Council Area Development in the North West Region, Cameroon
}

\author{
Mbanga Lawrence Akei ${ }^{1}$ \\ ${ }^{1}$ Department of Geography, University of Bamenda, Cameroon \\ Correspondence: Mbanga Lawrence Akei, Department of Geography, University of Bamenda, Cameroon. E-mail: \\ mbangalaw@yahoo.com
}

Received: October 7, 2014 Accepted: October 27, 2014 Online Published: January 28, 2015

doi:10.5539/jsd.v8n1p93

URL: http://dx.doi.org/10.5539/jsd.v8n1p93

\begin{abstract}
Regional institutions remain a spring board for the development of the rural council areas in the North West Region of Cameroon. An example is the Grassfield Participatory and Decentralized Rural Development Project, GP-DERUDEP operating in the North West region of Cameroon. These institutions carry out innovations in the council area development process. Today, with specific or common development policies they make significant contributions to the council area development process. They use the council areas as the unit for development activities and international institutions, the local councils, village organizations and the council area population as their partners in development. This study brings to focus the policies and actions as well as the performance of GP-DERUDEP, a regional development institution analyzing its contributions in the development process. The methodology consisted of a study of published and unpublished scientific documents and project institutional reports on development activities in the various council areas. This was completed with field survey in project areas. The result is revealing as evidence in the council areas show a significant innovation of the development process through capacity building of beneficiaries and the construction of socio economic infrastructure. But there is need for a close monitoring of the realizations especially the physical infrastructure if sustainable quality service provision is to be assured.
\end{abstract}

Keywords: institutions, area development, innovations, development process, participation and projects

\section{Introduction}

Institutions as a whole remain a springboard for development (Doner, 2010). Regional institutions play a very important role to the development of council areas in the world today. They have improved through innovations the development process. Though they play the same role of resource mobilization, capacity building of grassroots population, resources distribution all culminating to project execution, they have brought in several innovations or changes to this process. The constant increase in the population of the world and the important socio economic role of rural council areas today such as the feeding of the urban population simply add to the many reasons for governments through institutions to focus on the need to improve on the living conditions of the rural dwellers. Investments must be done in every sector of activity especially the non-farm. Socio economic infrastructure must be put in place (Mbanga, 2003). Vladislav and Sabine, (2008) in comparing the rural to the urban areas commented that in all regions of the world, rural areas are facing many similar challenges. Compared with urban territories, rural areas are often marked by low per capita income levels, low employment opportunities, unfavorable demographic situation, low population density and poor infrastructure. The level of economic development of rural areas has often lagged behind that of urban ones. Karlheinz, Talis and Gianluca (2009), commented that for these reasons rural areas and communities are becoming a very important starting point and platform for sustainable development. They attributed this to the fact that farmers who are the majority in rural areas are very important socio economic and cultural actors. The development of the rural council areas has never been neglected as every government in both the developed and developing countries has a rural development policy with institutions for implementation in the field. In Cameroon, these institutions include the councils and their partner institutions like the National Community Driven Programme, PNDP, the Community Development Support Project, PADC, the North West Development Authority and its sub project the Grassfield Participatory and Decentralized Rural Development Project, GP-DERUDEP. They all operate either at the national or regional scales. A variety of programs and projects have resulted from these rural development 
policies and institutions with the important objective to uplift the general well-being of the rural population in the economic and the social sectors.

According to Wijayaratna (2004), the realization of effective rural development requires complementary efforts such as developing and strengthening local institutional capacities, improving rural infrastructure and related services, a supportive policy framework, developing agriculture as well as rural industries and other non-farm activities, provide education, skill training, health and other essential services and most importantly, measures to ensure socio-economic and environmental sustainability of such efforts. This is supported by Doner, (2010) citing Hoff and Stiglitz, (2000), who affirm that there is a growing consensus of the gains to be reaped from collective work of several independent actors and managed by institutions. In the development of rural council communities, the coordination of various rural development activities is indispensable to maximize and sustain rural development efforts. This has been accomplished with the adoption of an Integrated Rural Development (IRD) strategy in many countries which usually require the establishment of a central coordinating organization at the national level. The important role of development institutions in the putting in place of policies which are transformed into strategies, programs and projects is worth mentioning.

The government of Cameroon is conscious of the important socio economic role of the rural council areas and the need to improve on the conditions of the rural dwellers. Since independence it has pursued a rural development policy through heavily subsidized agricultural projects in production and marketing, supporting and advising other agricultural institutions and farmers in their areas of operation, (Baye and Amungwa, 2002). It created development institutions of regional interest such as the Ombessa Development Authority, the Wum Area Development Authority, the North West Development Authority, the South West Development Authority and the Mount Mandara Integrated Development Authority. Also of national interest are the Community Development Support Project and the National Community Driven Program. Significant changes for development in rural council areas have been initiated by the efforts of these development institutions. They have multi-sectorial goals and have been a common feature of Cameroon's rural development endeavours. These institutions were set up to coordinate the expertise of multi-disciplinary teams of technicians, engineers, agronomists, economists, rural sociologists, geographers, soil scientists, doctors, etc. They operate in areas with development potentials, but which are inhibited by problems such as none, few or dilapidated socio economic infrastructure, low technical endowment and support, remoteness and rural exodus. They operate at the national, regional and divisional scales and in specific geographical settings.

\section{The Study Matrix and Methodology}

\subsection{The Study Matrix}

The North West Region lies between latitudes $5^{\circ} 43^{\prime \prime}$ and $7^{\circ} 9^{\prime \prime} \mathrm{N}$ and longitudes $9^{\circ} 13^{\prime \prime}$ and $11^{\circ} 13^{\prime \prime} \mathrm{E}$ and covers about $17.400 \mathrm{~km}^{2}$. It is bordered in the North and West by the Republic of Nigeria, in the South by the West and South West Regions of Cameroon and in the East by the Adamawa Regions. The Region is divided into seven Divisions; Boyo, Bui, Donga-Mantung, Menchum, Mezam, Momo and Ngoketunjia. The seven divisions are sub divided into council areas which respects the sub divisional limits. There are 34 councils in the North West Region (Fig I). Councils remain the main grass root unit for development with the local government therefore as the main partner for several state institutions in the process of development planning, project execution and monitoring for sustainability. 


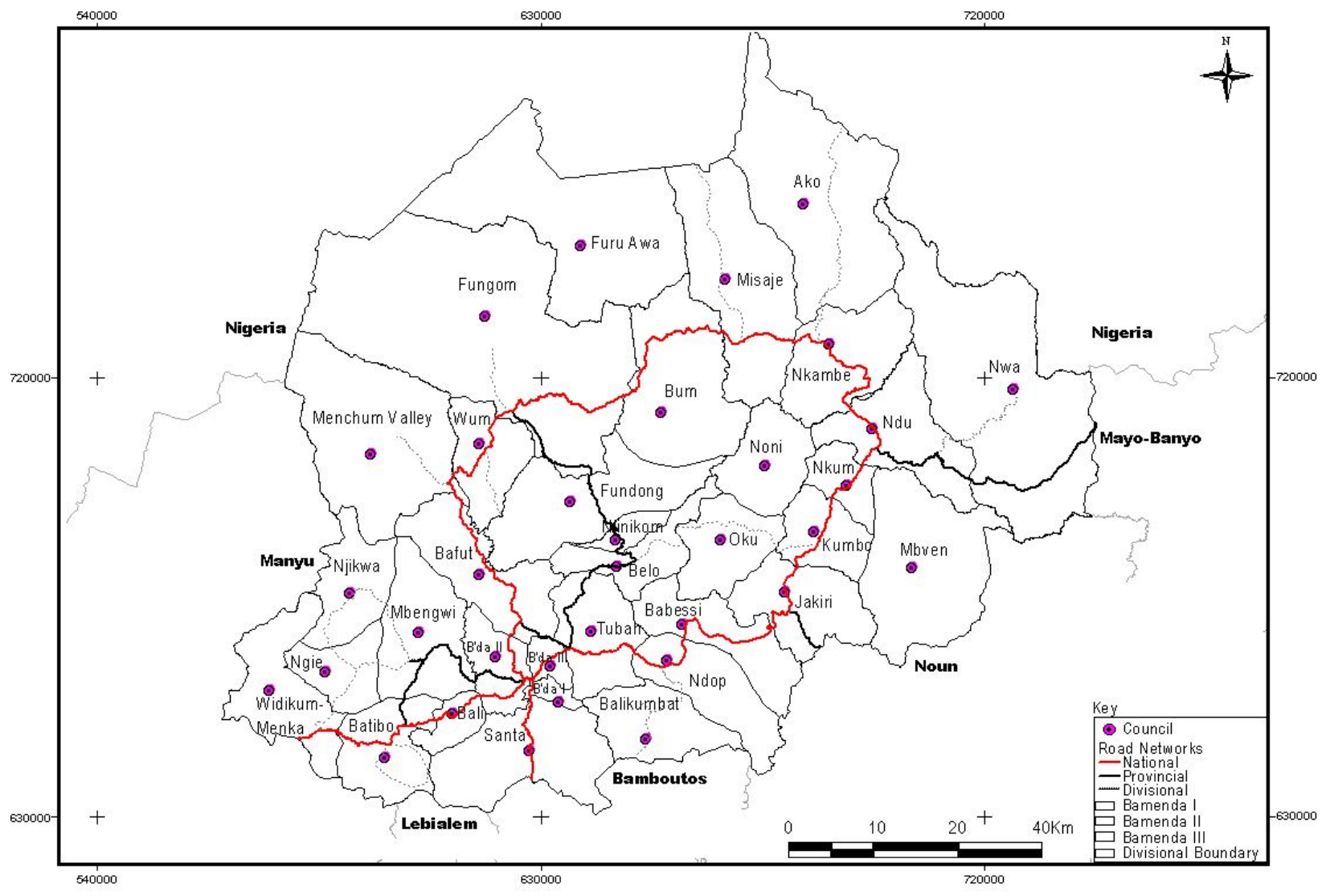

Figure 1. The North West Region showing councils

The North West Region has a population of 1.785285 , which is $9.2 \%$ of the total population of Cameroon. (BUCREP, 2010). Its topography can be classified into three main zones: the low altitude $(<900 \mathrm{~m}$ a.s.l), the average altitude $(900-1500 \mathrm{~m}$ a.s.l), and the high altitude $(>1500 \mathrm{~m}$ a.s.l). The annual rainfall varies from $1300 \mathrm{~mm}$ in the Ndop plain to over $3000 \mathrm{~mm}$ in mount Oku. The Region has several soil types on which a variety of crops are cultivated. The soils are gradually being modified by weathering and human activities (farming, construction and burning). In general, farming in the North West Region is extensive and dominated by four main agricultural domains: crops, livestock, aquaculture and non-conventional activities like bee farming.

\subsection{Methodology}

Secondary data are from a selective review of published and unpublished documents on development institutions and on projects for rural development. The unpublished documents are academic dissertations and thesis link to the theme, project reports on several institutions involved in rural development, especially GP-DERUDEP and the councils. These documents assess the results of specific rural development projects, while others synthesize and compare findings and lessons across a series of projects. They focus on various subsectors, such as farmer credit, irrigation, rural roads and integrated rural development as a whole. They also treat crosscutting issues such as development management, project design, execution, evaluation and monitoring. Primary data was collected in project areas through direct observation of the state of realized projects. Project areas for survey included all the 34 council areas in the North West Region as on Fig 1. Interviews were carried out with beneficiaries and institutional representatives as well as participant observation in ongoing projects.

\section{Problem Description}

The objective for the development of rural council areas is to improve on the living conditions of the people. In the North West Region, health care infrastructure is inadequate especially in the Menchum and Ngoketunjia divisions. Less than $40 \%$ of the population has access to medical consultations. This is partly attributed to the distance of the health care establishments in the rural council areas and partly to the fact that most people resort to traditional treatment because of high cost of medication and poverty. School infrastructure in rural council 
areas is in a deplorable condition as the classrooms are in sundry bricks without doors and windows and with uncemented floors. Over $95 \%$ of the schools in the rural areas suffer from inadequacy of teaching staff at all levels (nursery, primary and secondary schools). The farms to market roads are bad and farmers are forced to sell cheap to intermediaries who manage to reach the rural council markets. The marketing of food crops is poorly organized. The non-transformation of the crops as a result of limited processing facilities and insufficient knowledge on processing also constitutes a major problem. The non-availability of electricity in most rural council areas of the Region makes it difficult for processing to be carried out on a large scale. High post-harvest losses are registered due to poor harvesting and storage techniques. Negative consequences witnessed during transhumance include high death rate of calves due to hunger, pests and rampant farmer/grazier conflicts and crop damages. Major livestock infrastructure such as slaughterhouses, modern vaccination and weighing crutches are lacking in most parts of the Region. The low telephone, radio, television and internet coverage of the Region places a serious barrier to communication and information. Information on opportunities especially in the agriculture, marketing, employment and educational sectors are hardly communicated from the urban to the rural council areas on time. Most of the existing potable water installations have poor sanitation conditions. More than $90 \%$ of the existing community water supply schemes do not have maintenance equipment and trained technicians to carter for the tanks and standpipes. As such, damaged stand taps or leaking tanks and pipes are usually abandoned. There is insufficient fund to extend existing schemes and shortage of water during the dry season. In a bid to provide solutions to some of these problems, the Grassfields Participatory and Decentralised Rural Development Project (GP-DERUDEP) a sub project of the North West Development Authority was put in place. This study brings to focus the policies and development activities of GP-DERUDEP, analyzing its contributions in the development process in rural council areas of the North West region.

\section{Literature Review}

\subsection{Development Institutions and Partners: Innovating in Projects for Rural Council Areas Development}

Supported by the opinions and citing the works of Olatunbosun (1976), Williams (1978), Lele (1979), Idachaba (1980) and Ogunfiditimi (2000), Akinleye, Awoniyi and Fapojuwo (2005) considered rural development as the outcome of a series of quantitative and qualitative changes occurring among a given rural population and whose converging effects indicate, in time, a rise in the standard of living and favorable changes in the way of life of the people concerned. The authors viewed rural development from various perspectives. They pointed to the need for improvement in rural living conditions and standard of living of the rural populace. Rural development is based on the need to balance the pattern and direction of government for the benefit of both the urban and rural sectors and provide technical requirements for speeding up economic growth in the development. The important place of institutions is recognized. According to Umar, (1992) development institutions are the nerve-center of rural development. They are involved in the implementation of governments' policies in the field by transforming objectives into projects that are realizable and measureable. They are involved in the complete rural development project cycle from problem identification, through capacity building of beneficiaries, finance sourcing, project execution and monitoring. They are financially autonomous or non-autonomous institutions created to realize the objectives of socio economic and infrastructure development in rural council areas. These institutions have all left a memorable mark in terms of realizations in various countries or regions.

In evaluating the National FADAMA Development Project, NFDP approach in Nigeria, Akinleye et al, (2005) identified several root causes in their shortcomings such as the absence of capacity building at the local level, little or no accountability and little involvement of private and research bodies in local government rural development. The initial NFDP was initiated to address some of the factors that militated against the full realization of the potential benefits of agricultural production activities in rural areas in Nigeria. Some of these factors were poor development of rural infrastructure, low investment in irrigation technology, poor organization of farmers and limited access to foreign exchange for the importation of irrigation equipment.

Durdica Z., Tito, Ivo and Vjekoslav (2003), analyzing the project approach for rural development in two villages of specific state concern in Croatia, the villages of Jazavice and Rodanik, recommended a multidisciplinary approach because of the complexity of the problems related to the integrated development of rural council areas, and specifically the areas that suffered war damage and demand fast reconstruction because of economic and humanitarian reasons. The solutions they suggested should include a development policy that would involve both the structural and territorial dimension, i.e. a modern territorial and economic approach which still asks for decentralization leading to increase in local government and self-government authorities.

In an evaluation of the experiences with rural development on specific project factors affecting performance of the Agency for International Development, Binnendijk, (1988) pointed out that there is no superiority of any one 
organizational model for implementing rural development activities. Instead, the answer may lie in assessing the functions required in implementing a rural development project and then establishing an appropriate mix of organizations that maximizes the advantages of each while minimizing their weaknesses. There are both successful and unsuccessful project performances. She added that the appropriate choice of organization for implementing rural development projects depends on numerous factors, including the project's objectives, scale, type of activity, and potential for profitability. In her analysis she mentioned the fact that projects managed by centralized line ministries are most appropriate when the aim of the project is to influence political or policy objectives. Some rural development projects, especially integrated rural development projects, have attempted to bypass some of the shortcomings of government agencies by creating special project management units with varying degrees of autonomy from regular government procedures. This shall be clearly observed in the functioning of the Grass fields Participatory and Decentralised Rural Development Project. Such institutions vary greatly in their capabilities.

According to Menjo (2003) and Shiuh-Shen, (2006), institutional environments significantly influence access to economic assets that determine the welfare status of the rural people. Menjo, (2003), appealed to the framework of institutional economics to illustrate the influence of rural institutions in determining access to and returns on primary assets that are contingent to poverty outcomes in two villages in Cameroon, Vekovi and Ekona. Poverty is quite common in the rural areas, in part, because of the lack of civic education and the institutional arrangements that influence rural activities and asset accumulation. He concludes that the lives of the rural people, like that of every other citizen, are conditioned by the institutions that mediate and enforce laws and regulations to govern their harmonious existence. Shiuh-Shen, (2006) focused on the Local innovations brought by institutions during the post Mao era in china. He identified several ways that includes amongst many the introduction of new reforms and the flexible shifting of resources allocations. The aspect of innovations by development institutions for rural areas is supported by Karlheinz, (2009) in his analysis. He considered institutional innovations as the facilitators of change and adjustments in rural areas which are becoming more and more multifunctional and thus the importance to give to the rural people the necessary aid to development. Institutions must innovate if the development process in rural council areas has to take off and be sustainable. In his analysis of self-help efforts and rural development in Cameroon with the case study of the awing community in the North-West region of Cameroon, Mbafor, (1998) insisted that rural development should be the result of a partnership between the government, development agencies and the people and they all make up the institution for rural development. The Ndong Awing Cultural and Development Association in this case represent the people. The Grassfields Participatory and Decentralised Rural Development Project involve the government of Cameroon, the African Development Bank as the main funding body, the councils and the village communities as partners to development. Today's rural development institution is therefore made up of all these partners.

\subsection{A model for Rural Development}

The result of several studies has led to the development of models on rural development. Mbanga, (2005) proposed a model for rural development (Fig 2) with development institutions, the council and village development associations as partners. 


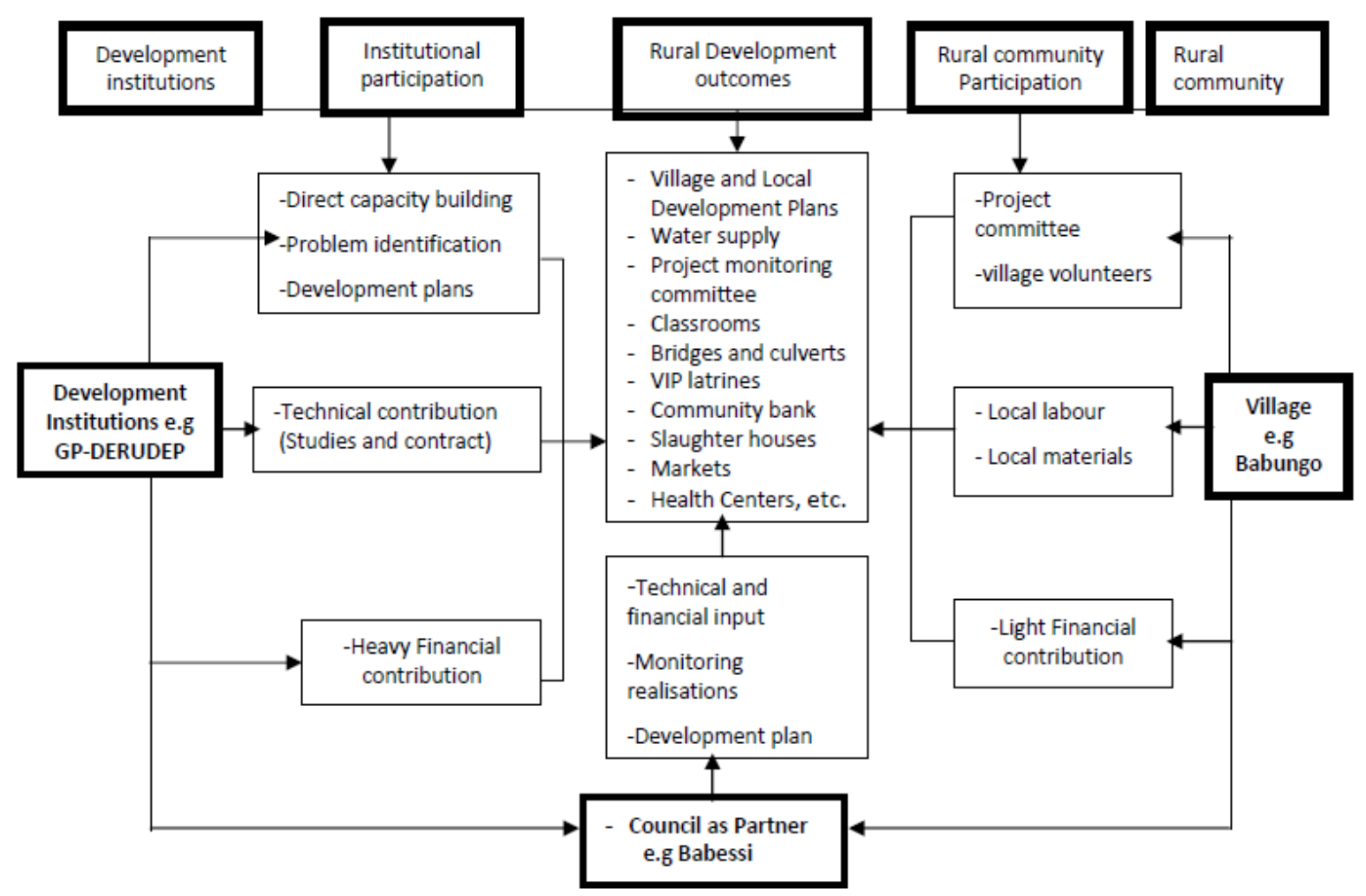

Figure 2. Rural development model

Source: Mbanga, 2005.

Though the centralised decision making role of development institutions had undergone serious criticisms over the 80s and the 90, this model gave development institutions the pride of place in the management of rural development projects for sustainability. A development institution at the regional level and close to the grassroots, the beneficiaries is an important innovation. Decisions are taken at the regional level where the beneficiaries reside and not the national capital at the central services of decision making. The model proposed also the village communities occupying an important position. It was not the same several decades ago. The contribution of development institutions begins with capacity building of the village communities, working with the people to identify and prioritised their problems which can then be inserted in a development plan. Technical and financial contribution comes not only from the development institution but also from the village communities as they contribute in kind and in cash providing skilled and unskilled labour. These communities can also carry out direct investment done by rich individuals or elite or by the village development association. The model gives an important place to the local councils which are managed by the grassroots, population. This is the institution for local development by the people and for the people. The council is the owner of the Local Development Plan produced in partnership with the development institution and not the ministry or a central body.

The model identifies three partners in development, the development institution like GP-DERUDEP, the council which is the local government and the village communities that make up the council area. Each has a role on its participation to the development outcomes in the council area. The development institution is the main funder of the development activities for it provides heavy finance. It coordinates problem identification, capacity building and the conception of a development plan for the village communities. Several VDPs are put together to be a council development plan. They supervise projects closely. The development belongs to the council. The council can continue its implementation in the absent of the development institution, the main funder. The community contributes in cash and in kind. Some chosen delegates from the villages make up the project committee through which they are empowered on the management of development activities and projects. The village communities provide small financial contribution. The council assures continuity in development activities especially in the monitoring of realisations. This model developed in 2005 fits in the innovated or new development process adopted by GP-DERUDEP. 


\section{Results}

5.1 The Grassfields Participatory and Decentralised Rural Development Project (GP-DERUDEP) in the North West Development Authority, MIDENO: Three Partners in Development by Participation

After independence development activities in Cameroon were elaborated, implemented and evaluated every five years following the five years development plans. The legal and institutional framework for development in Cameroon has greatly evolved towards the creation of both national and regional institutions that has the objective of systematically planning, execute, evaluate and monitor development endeavors at a regional scale. The North West Development Authority, MIDENO was created in 1981. Its main mission was to promote integrated rural development in the entire North West Region. Towards the end of the second phase of MIDENO, it became evident that most of the planned activities had not been realised. A baseline study was carried out in Region in 1999 by the African Development Bank and revealed that more than $70 \%$ of the population of the Region still live below the poverty line. In order to remedy this situation, correct the errors of past projects and improve on the living conditions of the people, the government of Cameroon and the African Development Bank initiated the Grassfields Participatory and Decentralised Rural Development Project (GP-DERUDEP) or the Grassfields Project.

The Grassfields Project (GP-DERUDEP) is a poverty alleviation project initiative co-funded by the government of the Republic of Cameroon, the African Development Bank, (ADB) through the African Development Fund (ADF) and the beneficiary communities making up the three partners in development by participation. The objective was to contribute to poverty alleviation in the rural council areas of the North West Region through increasing agricultural output and improving their Socio-economic environment. Its zone of intervention covers the entire North West Region of Cameroon. To achieve its objectives, GP-DERUDEP used the following four components; project coordination and management, agricultural development, capacity building and the rural infrastructure support sector.

The rural infrastructure support sector as a component ensures the provision of rural infrastructure at the village and council levels such as potable water schemes, health centres, storage houses, pastoral water points, farm to market roads, community welfare centres and classrooms, which are co-financed with the beneficiaries. Though realised by enterprises, the beneficiaries fully participated. Their participation at not more than $30 \%$ of the total cost of the project was in the form of labour and the provision of local materials. Sensitisation, capacity building and organisation of the beneficiaries were carried out in prelude to project realisation so as to assure their massive participation. The total cost of the GP-DERUDEP was estimated at 15.730 Billion CFAF with the ADB providing $84 \%$, the Cameroon government providing $10 \%$ and the beneficiaries participating financially to the realisation of projects in the area with $6 \%$ (Table 1 ).

Table 1. Financial details of financing sector and partners of GP-DERUDEP

\begin{tabular}{lcc}
\hline Components & Amount & \% \\
\hline A) Financing sector & Total & \\
Agriculture development & 3.157 & \\
Capacity building & 1.899 & \\
Rural infrastructure support sector & 6.817 & \\
Project management & 1.800 & \\
Basic cost & 13.673 & \\
Physical unforeseen & 818 & \\
Provisions for price increase & 1.239 & \\
Total & 15.730 & \\
b) Financing bodies & Total & \\
African Development Bank & 13.195 & $84 \%$ \\
Cameroon government & 1.572 & $10 \%$ \\
Beneficiaries & 963 & $6 \%$ \\
Total & $\mathbf{1 5 . 7 3 0}$ & $\mathbf{1 0 0 \%}$ \\
\hline
\end{tabular}

Note. Amount in Francs CFA

Source: ADB, 2003 
The government's goal of the project was to contribute to poverty reduction and to enhance food security in rural areas. More specifically, the project was aimed at increasing the incomes of small holders in the Grassfields region through increased agricultural production and improved socio-economic environment. An implementation unit placed under the supervision of MIDENO was in charge of its full implementation for a period of six years. A project mid-term review report of 2005-2007 presented in December 2007 on the monitoring and evaluation of the activities of GP-DERUDEP led to the extension of the project period to 2010 and not December 2009 as initially stated. Physical realisations of the project as of December 2007, was $20 \%$ of the earmarked activities under the agriculture development component, $20 \%$ for the capacity building component, $2.5 \%$ for the support to rural infrastructure component and $48 \%$ for the coordination component of the project. In summary, of all the project components, the physical realisation rate was assessed at $23 \%$. For these reasons, Mbunwe (2007) affirmed the disappointment of the African Development Bank with the GP-DERUDEP project management. The project by this date had already consumed $18.76 \%$ of ADB budget allocation and $24.5 \%$ of the government of Cameroon's budget allocation. The late start of financial disbursement, the suspension for slightly over a month of the project in May 2007, the long delays experienced in the processing of tender files and in the signing of protocol agreements with partners, the inefficiencies of project partners in justifying budgets disbursed to them, lateness in the realisation of priority studies and documents caused the lateness in the project. The summary assessment of the project status concluded that the effervescence experienced within the project as concerns efficiency of processing documents, the added skills of partners at the beginning in justifying expenditures, the increasing Cameroon government's goodwill in meeting its obligation, critical studies and manuals already established and the smooth integration of the three required technical assistances to the project gives high indications that the project has gotten to a take-off stage that shall see huge budgetary consumption and activity realisations come 2009 and onward. This was confirmed with the presentation of a report in January 2008 showing some 140 villages in the North West Region, identified to benefit from funds for the financing of community development projects in the domains of pipe borne water schemes, health and school infrastructure. This report was published after the mid-term review of the activities of GP-DERUDEP.

\subsection{The Development Process as Practiced by GP-DERUDEP}

GP-DERUDEP adopted the bottom-top development process because it aims at involving the grassroots, population to achieve sustainable development. In this process the beneficiaries of its development activities are actively involved and participate at all stages of the development process. It instituted the Local Development Fund, LDF with the specific objective of improving the living conditions of the population of rural communities through the construction of rural infrastructure such as water supplies, health centres, and classrooms. The philosophy and principles governing the LDF are based on five key concepts namely, participation, decentralisation, ownership building, accountability and sustainability. Every village in the North West Region was eligible to benefit from the Local Development Fund but only those villages with the minimum characteristics expected of potential beneficiaries were selected. These villages showed proof of development awareness and commitment, structural preparedness and social stability. In choosing the beneficiaries of the LDF, many points were taken into consideration such as the level of organisation of the people committed to work together for the well-being and sustainable development of their village, a village where there is solidarity and collaboration amongst members, where there are village leaders with the political will, commitment, energy and demonstrated dedication to the development of the village and where there exist a legally recognised Village Development Association with dynamic members willing to identify their needs and problems and seek solutions collectively to them. The LDF financing facility is for 140 communities and remains one of the most important operational tools of this body.

\subsection{Recognised Management Structures for the Local Development Fund}

The basic structures for development actions at the grassroots, recognised by GP-DERUDEP for the LDF are the Village Development Associations, VDAs. The LDF provides a structure for the VDAs, the qualities of its officials and the component of its general assembly but which are not different from the realities existing in the field. The management of the LDF is done at three levels, the village, the council and the Divisional levels. At the village level, the VDAs are obviously the main development partner. Nevertheless a project committee is put in place to manage projects at the community level. The Local Development Fund Municipal Management Committee, LDFMMC, manages the LDF at the local council level. It is headed by the mayor and has representatives of the VDAs of the villages in the council area. It validates the Village Development Plans. The mayor of Babessi council for example in his capacity as chairman of the LDFMMC for Babessi council published a call for tender for the study of community infrastructure, training and supervision works funded by the LDF with reference number $13 \mathrm{C} 116 / \mathrm{VOLI} / 65$ of 12/12/2008. The LDFMMC also serve as the community 
authority for the procurement of goods and services within the LDF at the Divisional level and is headed by the Lord Mayor of the council at the Divisional headquarters. In this case the Lord Mayor of the Ndop council for Ngoketunjia Division. Made up of all the mayors of the Division, the GP-DERUDEP program unit representative, the delegate of MINADER and the Divisional chief of rural engineering, the LDFDMC coordinates and supervises the LDF activities in the Division, approves the annual budget and programs of the LDFMMC and validates the Local Development Plans drawn from the Village Development Plans.

\subsection{The Elaboration of the Village Development Plans, VDP: Involving the Communities for Project Identification and Priotisation}

To permit the implementation of the LDF to improve on the condition of the people by providing their felt needs, the villagers or beneficiaries, guided by the LDFMMC facilitators identified their needs and organised them into coherent documents called the Village Development Plan, VDP and Local Development Plan, LDP. These are a comprehensive and inclusive document that describes the activities planned by a village community or a council through a participatory process to address priority problems affecting the community over a given period of time. Two sets of two facilitators recruited by the LDFMMC from a local NGO, guides the villagers. After some preliminary studies in the village, the general village assembly meets to identify, analyse and prioritise their problems. This was programmed for two days per village and lasted up to 2008 for the entire Region. Consultants served as facilitators. The general assemblies were attended by men, women and youths. Members and executive members of the VDAs in this area attended the general assembly and this was an obligation for they are piloting development activities in the village. The elaboration of the VDP for the villages of Ngoketunjia division for example was done in the month of April, 2008 and the detail number of participants in the drawing up of the VDP is shown on table 2.

Table 2. Participation in the elaboration of the VDP for Ngoketunjia villages

\begin{tabular}{lll}
\hline Village & Dates & Attendance \\
\hline Bamali & $8^{\text {th }}-9^{\text {th }}$ April 2008 & 119 \\
Bamunkumbit & $8^{\text {th }}-9^{\text {th }}$ April 2008 & 105 \\
Bambalang & $9^{\text {th }}-10^{\text {th }}$ April 2008 & 117 \\
Baba I & $9^{\text {th }}-10^{\text {th }}$ April 2008 & 159 \\
Bangolan & $10^{\text {th }}-11^{\text {th }}$ April 2008 & 161 \\
Bafanji & $10^{\text {th }}-11^{\text {th }}$ April 2008 & 55 \\
Bamessing & $10^{\text {th }}-11^{\text {th }}$ April 2008 & 191 \\
Bamunka & $11^{\text {th }}-12^{\text {th }}$ April 2008 & 123 \\
Babessi & $11^{\text {th }}-12^{\text {th }}$ April 2008 & 139 \\
Balikumbat & $12^{\text {th }}-13^{\text {th }}$ April 2008 & 112 \\
Baligashu & $12^{\text {th }}-13^{\text {th }}$ April 2008 & 85 \\
Babungo & $13^{\text {th }}-14^{\text {th }}$ April 2008 & 129 \\
Baligansin & $14^{\text {th }}-15^{\text {th }}$ April 2008 & 71 \\
Total & & $\mathbf{1 . 5 6 6}$ \\
\hline Source: Conpil & & .
\end{tabular}

Source: Compiled from GP-DERUDEP 2008 reports on the elaboration of Village Development Plan for the 13 villages of Ngoketunjia Division

This is not new to the people of this area for it was not the first time they were carrying out such an exercise.

\subsection{From the Village Development Plan to the Local Development Plan}

In a meeting of the Local Development Fund Municipal Management committee attended by delegates of the different VDAs as well as village and council representatives, the Village Development Plans for the villages of the council areas were presented by the president or the representative of the VDA, reviewed, defended and validated. After the approval of the VDPs, a Local Development Plan was drawn up for priority project 1 for every village. The Lord Mayors in their capacity as the Chairman of the LDF Divisional Management Committee later convened a general assembly and after the presentation of the LDP by the mayors of the council 
areas, they were reviewed, defended and validated. A budget was also approved for the LDFDMC. From the VDP to the LDP, it is confirmed that the priority projects are the choices of the people and their felt needs. The communities were fully involved in the elaboration of the VDP and their representatives. The executives of the VDAs were always present to present their VDP and defended their choice of one project or the other identified in a general assembly by the men, women and youths of the village. GP-DERUDEP seeks to make a difference in development by participation. It conceived a community participation strategy package. Table 3 show the projects validated in the Local Development Plans for the villages of Ngoketunjia Division.

Table 3. Local Development Plan Priority project 1 for council areas in Ngoketunjia Division

\begin{tabular}{|c|c|c|c|c|}
\hline \multicolumn{5}{|c|}{ Villages } \\
\hline Babessi & Bangolan & \multicolumn{2}{|l|}{ Babungo } & Babessi \\
\hline \multirow[t]{8}{*}{ Projects } & -Construction of & -Construction of & -Construction of & -Construction of 14 classrooms; \\
\hline & Classrooms & Classrooms & classrooms; & G.S. Nchingong 2, Cameroon \\
\hline & Government Bilingual & Government Secondary & Government School (GS) & Baptist Convention (CBC) Mbow \\
\hline & Secondary School, & School Babungo & Mabwart and 2 at & 2, Government School (GS) \\
\hline & (GBSS) Bangolan and & & Government & Menua 2, GBHS Babessi 4, \\
\hline & the provision of 240 & & Ngwikem & Government Technical College \\
\hline & benches & & & (GTC) Babessi 2, Islamic Primary \\
\hline & & & & School (IPS) Mamam 2 \\
\hline Balikumbat & Bafanji & Bamunkumbit & Baligansin and Baligashu & Balikumbat \\
\hline \multirow[t]{7}{*}{ Projects } & -Rehabilitation & -Construction of storage & -Extension of water pipeline & -Construction of a bridge at \\
\hline & Scanwater scheme and & water tank and extension & from Bamunkumbit to & Ngongo-Njifowang and culverts \\
\hline & its extension to & of water to Manjong, & Baligahsu and Baligansin & on the Ngongo-Fombangum road \\
\hline & Mbalieh, Ntounkong, & Mbanka, Mulafi I and II, & ( Gahkat, Market Square, & \\
\hline & Membempa, Ekwo, & Mbantap, & Gahmban, Baligashu main & \\
\hline & Mbatong, Mbafang & Akumum and Alumdi & roads, four coners Ntenfon & \\
\hline & and Njantang quarters & Markets & and Njenka II) & \\
\hline Ndop & Bambalang & Bamali & Bamessing & Bamunka \\
\hline \multirow[t]{8}{*}{ Projects } & -Rehabilitation & -Reinforcement of Tulah & -Completion & -Construction of 3 \\
\hline & Scanwater system and & water catchment and the & Mbelui-Njingzing bridge & catchments below Ngokentunjia \\
\hline & supply to all quarters & extension of water & & hill and the rehabilitation of the \\
\hline & & supply to Mbema & & council water scheme to supply \\
\hline & & through Melah and & & rural quarters ( Tuloh, Bekew, \\
\hline & & Mewefou & & Ntangoh, Messi, Ngwalla, Mesoh, \\
\hline & & -Rehabilitation & & Mbankah, Mbembony) \\
\hline & & existing water scheme & & \\
\hline
\end{tabular}

Source: Information collected by author in attendance, 2008 and completed in GP-DERUDEP, 2009.

\subsection{The Contribution of GP-DERUDEP to the Development Process of Rural Council Areas in the North West Region}

The project's results are grouped within the relevant project components which are capacity building, agricultural development and support to rural infrastructure. Under capacity building the project has trained 35 Community Development Agents of the Ministry of Agriculture and Rural Development and 320 municipal councilors from all the councils of the North West Region. It also trained 20 Trainers in adult literacy for literacy training, strengthened 3500 professional organizations and sensitized 12,700 persons in contributing to the prevention and control of HIV/AIDS and endemic diseases. It has increased agricultural output, through 
expansion of arable areas, intensification on existing farms and the training of producers. It has facilitated the marketing of agricultural produce by enabling access to marketing facilities for requested communities and ensuring the effective functioning of the Market Information System of the Region. Under support to rural infrastructure, it has facilitated the evacuation to the markets of agricultural produce, through the rehabilitation of $247 \mathrm{~km}$ of agricultural service roads in the Region. It has financed the construction of community development infrastructure, using the Local Development Fund and has trained the local project management committee members in monitoring and managing realizations for sustainability. The Project has realized significant achievements in the domain of its expected outputs. Under agricultural development, the project has enabled the increase in the area of cultivation of farm-lands by 885 ha on potatoes producing 17.700 tons of potatoes, 460 ha on rice producing 620 tons of rice, and 140 ha on maize producing 280 tons of maize. The Project has also constructed various infrastructures throughout the Region as shown on table 4.

Table 4. Realized infrastructure projects by GP-DERUDEP in the North West Region

\begin{tabular}{llllll}
\hline \multicolumn{7}{l}{ PROJECT ELEMENTS } \\
\hline DIVISION & Sales points & Slaughter houses & Cattle dips & Amount in FCFA & Present State \\
Momo & 7 & 6 & 2 & 162.238 .721 & Good \\
Ngoketunjia & 5 & 3 & 2 & 124.704 .037 & Good \\
Bui & 7 & 4 & 1 & 150.705 .907 & Good \\
Donga Mantung/Boyo (Fonfuka) & 6 & 3 & $1+1$ clutch & 160.250 .610 & Good \\
Menchum and Mezam & 5 & 4 & $1+1$ clutch & 136.673 .812 & Good \\
Mezam and part of Momo & 6 & 7 & 1 & 139.776 .075 & Good \\
\hline
\end{tabular}

Source: GP-DERUDEP, 2010 and Field survey, 2013

These infrastructures are in used since completion and facilitate care, handling and marketing of farmers produce. An example is the Sales point constructed in Mbah in the rural area of the Kumbo Council. The project also rehabilitated several farm to market roads throughout the Region like the Mbokam road. Details of some of the roads rehabilitated are shown on table 5 .

Table 5. Some rural roads rehabilitated by GP-DERUDEP in the North West Region

\section{PROJECT ELEMENTS}

\begin{tabular}{llll}
\hline Division & \multicolumn{1}{c}{ Project } & Amount in FCFA & State \\
Momo & Rehabilitation of 36km of rural road & 504.665 .200 & Good \\
Mezam / Menchum & Rehabilitation of 56km of rural road & 517.270 .850 & Good \\
Ngoketunjia / part of Menchum & Rehabilitation of 72.7km of rural road & 666.600 .113 & Good \\
Donga mantung and Bui & Rehabilitation of 89.2km of rural road & 661.477 .267 & Good \\
Boyo & Rehabilitation of 34.7km of rural road & 40.000 .000 & Good \\
\hline
\end{tabular}

Source: Field survey, 2013

After the rehabilitation of these rural roads there was an increase in traffic volume. Communities which could only be accessed on foot, by motobike or a 4WD vehicle once a week, witnessed an almost $250 \%$ increase in traffic volume. The transportation cost for goods and persons from the various disenclaved communities has reduced by an average $45 \%$. The average price of farm produces in the disenclaved communities has risen by an average $15 \%$, providing more income to the farming population in the area. The production of the main agricultural produce in the disenclaved communities has risen by $60 \%$ due to increase market and hence increases household income. The post-harvest loss in these communities is at a decrease of an estimated $40 \%$ from almost $65 \%$. Several projects were realised in the education sector with classrooms constructed, rural water supply, health centres constructed or rehabilitated and equipped. Bridges and culverts as well as community halls were also constructed. These projects are spatially presented in several rural council areas as shown on figure 3 . 


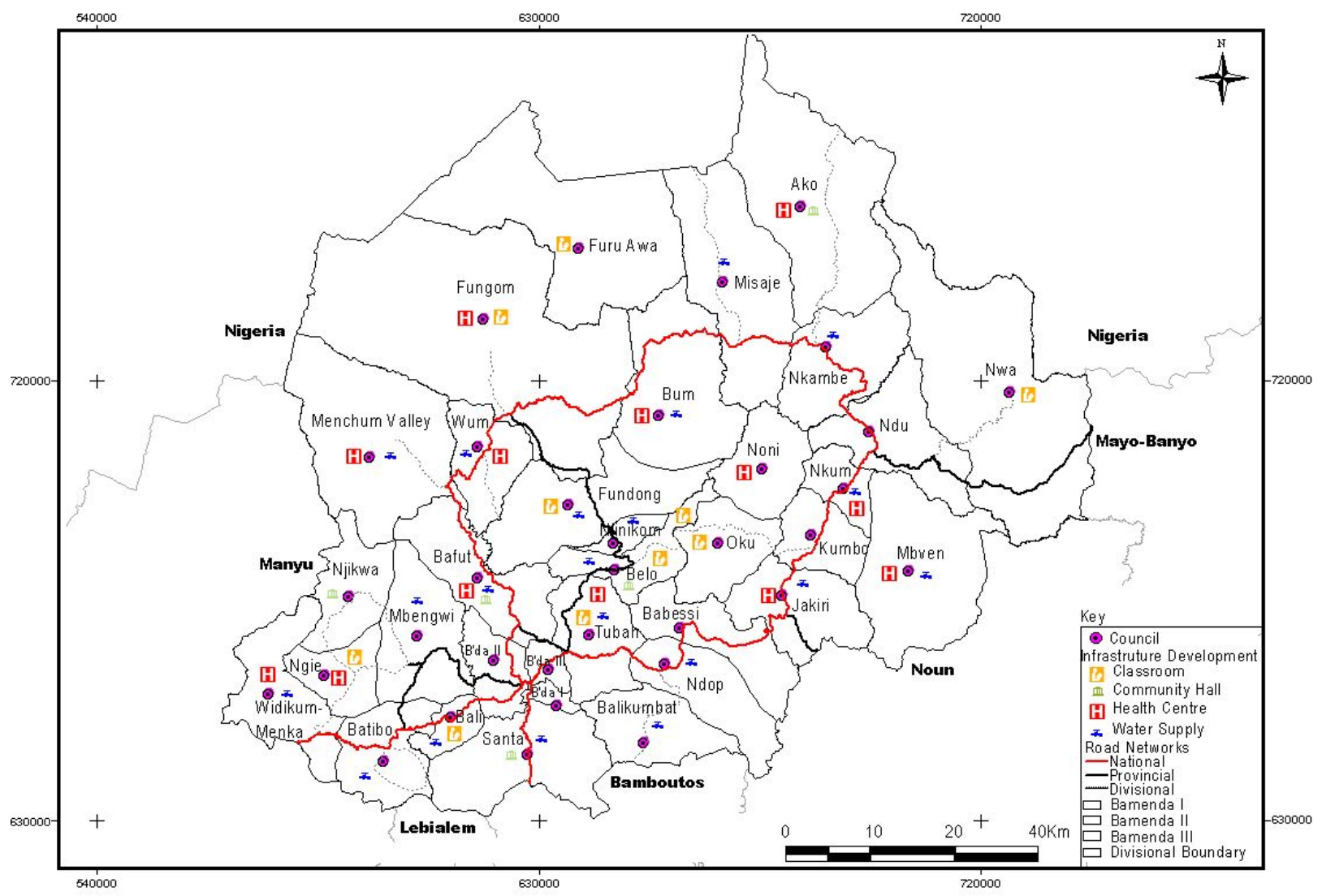

Figure 3. Spatial distribution of GP-DERUDEP's rural infrastructure projects in rural council areas of the North West Region

Source: GP-DERUDEP, 2010 and field survey, 2013

Bridges and culverts were also constructed to permit easy circulation of vehicles with goods, especially construction materials. This has led to improved housing conditions as many building are springing up due to the availability and reduced cost of building materials. Many sons and daughters of former enclave villages are returning home to settle as they can freely move around. Elites of the villages are paying regular visits to their families in the rural areas. Some neighbouring villages are digging their own roads to join the rehabilitated road. Crime rate has significantly reduced as many youths are now engaged in motorbike transport activities.

Hundreds of Classrooms have been constructed and handed to the beneficiary communities. For example two classrooms were constructed in G.S. Mbokop in the Ntamru community in Ndu Council. The enrolment of pupils and students in the various schools which have benefited from the construction of classrooms has risen to between 35 to $44 \%$. The attendance of pupils in school saw a significant rise of $70 \%$ as children were highly motivated to attend schools and sit in classes that are warm, clean and attractive. At the end of the school year the results improved also by $38 \%$ as mostly the examinations classes were using the new structures constructed which gave them and their teachers an appropriate and conduisive learning environment. Pupils are highly motivated to learn and the teachers are motivated to teach. Children are cleaner, healthier as frequent cases of cough and jiggers amongst pupils are no longer reported nor noticed.

Community Halls were constructed and handed to beneficiary communities. Attendance during community development meetings rose by $140 \%$ as more people and elites of the community felt more comfortable attending meetings in a neutral political, spacious and clean environment. Fund raising recorded a $276 \%$ increase from the previous trends. The construction of the community halls also motivated more frequent development meetings and other social meetings in the communities which rose by $100 \%$. Marriages and other ceremonies are now taking place in the rural council areas.

Water supply schemes were rehabilitated or constructed like the Njong Community Water Supply in Santa Council. The distances often covered mostly by women and children to fetch water has reduced by an average 
$89 \%$ in areas where water system projects were constructed. This is a reduction from an average $1.74 \mathrm{~km}$ before to only $100 \mathrm{~m}$ after. The recorded time used by the women and children to fetch water in the mornings and evenings reduced by $75 \%$ on the construction of the water systems in the communities. That is, from an average $1 \frac{1}{2}$ hours to 20 minutes. In few communities like Kucda in Batibo which have been using the constructed potable water for close to a year, the local hospitals recorded a drop in water borne diseases as typhoid, diarrhoea and dysentery by an average $52 \%$. The construction of the LDF potable water projects has provided access to potable water to a rural population of about 400.000 people in the North West Region.

Health centers were constructed and some rehabilitated and equipped. There is an improved access to medical services as patients are easily evacuated or medical personnel easily get into the villages. The distances travelled by the rural population within the communities concerned to access appropriate medical care is reduced significantly by about $90 \%$ e.g $17 \mathrm{~km}$ before to $1.5 \mathrm{~km}$ for Buku community in Ako council. Consultations and hospitalisation increased by about $250 \%$ since the communities now have easy access to the medical facilities.

\section{Discussion}

The major problems identified by the baseline study that was carried out in the North West Region as a whole and in rural council areas in particular leading to the creation of GP-DERUDEP were in the hard infrastructure sector. This included little or no drinking water supply, poor or no classrooms, no or unequipped health centers, no electricity or low coverage, enclave villages because of inaccessible roads, etc. The absence or the poor quality of such infrastructure in rural areas of many developing countries represents one of the most significant limitations to rural development. Adequate infrastructure lowers production costs, raises productivity and facilitates distribution for commercialization. Evidence in the rural council areas of the North West Region where such infrastructure has been put in place by the development institution, GP-DERUDEP and the communities show a significant contribution to economic growth. Communication and commercial transactions between the towns in this Region and the villages have been greatly improved. For example the periodic markets in these villages are now accessible in all seasons and middle men can easily buy and transport farm produce from these markets to sell in the towns. Most of these markets now have permanent structures where farm produce can be sold in good conditions.

Nevertheless, the contribution of such infrastructure put in place by development institutions to the development of these rural areas is complex. It has to be well maintained to assure a sustainable contribution to development as a whole and it has to expand fast enough to accommodate growth. Following the last census, $62.8 \%$ of the population of the North West Region lives in rural council areas with an annual growth rate of $2.5 \%$. This means there will be continuous pressure on the infrastructure put in place by the growing population and the expanding villages. Population growth simply means the extension of the build-up space and therefore the need for expansion of the infrastructure to these new areas. For population growth and others that come along with it to be accommodated, there is need to increase investments.

\section{Conclusion}

Development institutions have innovated the development process. The policy of development by participation with the rural council area population as partners with the government, the development institution and a donor institution is an institutional innovation which is producing positive results. The realizations of development institutions like GP-DERUDEP in rural council areas of the North West Region are contributions to poverty reduction, economic growth and the empowerment of the rural population. The innovations in the financial and technical contribution in the agriculture sector, capacity building and in the rural infrastructure sector is enormous. But studies by, Ngwa (1985), Ngwa (1987), Mbanga (2003), Fonchingong and Fonjong (2003), Moupou and Mbanga (2008) and Mbanga, (2010) on development activities in the North West Region of Cameroon have all concluded that it is not enough to simply meet demand by constructing a road, water supply, electricity, classrooms, health centers, etc. This has been done by all the rural development stakeholders with funds provided by donors or raised by Village Development Associations. The problem lies in the diminishing quality and services of these realizations with time. Physical infrastructure has been provided and management committees have been trained and put in place as it was done long ago. But there is need for a close monitoring of the degradation of these infrastructures by the state institutions having the responsibility if sustainable quality service provision is to be assured. For example the council must not allow the roads to degrade to an advance state before repair works are done. In this way, development institutions would have contributed to sustainable and not periodic rural development.

\section{References}

African Develoment Bank. (2006). Baseline study of the North West Province, Elaborated by Society for 
initiatives in rural development and environmental protection (SIRDEP)-Cameroon, Bamenda.

African Development Bank. (2003). Evaluation report for the grassfields participatory and decentralized rural development project, GP-DERUDEP. Yaoundé.

Akinleye, S. O., Awoniyi, S. M., \& Fapojuwo, E. O. (2005). Evaluation of the National Fadama Development Project approach to rural development: lessons for local government councils in Nigeria. Paper prepared for presentation at the Farm Management Association of Nigeria Conference, Asaba, Nigeria, October 18-20, 2005, 9p.

Baye, M. F., \& Amungwa, F. A. (2002). Training in partnership for development: the case of agricultural family schools in rural Cameroon. Pakistan Economic Social Review, XL(1), 35-55.

Binnendijk, A. (1988). A.I.D.'S experience with rural development: project-specific factors affecting performance. A.I.D. EVALUATION SPECIAL STUDY NO. 60 (Document Order No. PN-AAX-213 Center for Development Information and Evaluation, A.I.D.) Paper prepared for presentation at the seminar "Rural Development: Lessons From Experience" held at the World Bank Office, Paris, February 18-19.

Bureau Centrale de Recensement et d'Etude de la Population. (2010). Rapport de présentation des résultats définitifs. 66p.

Doner, R. F. (Ed.). (2010). Explaining institutional innovations. Case studies from latin America and East Asia. Social science research council, USA.

Durdica, Z., Tito, Z., Ivo, G., \& Vjekoslav, P. (2003). Project approach to the development of rural areas of special state concern, case study of Jazavica and Rodanik. Faculty of Agriculture, Zagreb, DRU[. ISTRA@. ZAGREB GOD. 14 (2005), BR. 1-2 (75-76),STR. 251-267.

Fonchingong, C. C., \& Fonjong, L. N. (2003). The concept of self reliance in community development initiatives in the Cameroon grass fields. Nordic Journal of African Studies, 12(2), 196-219.

Grassfield Participatory and Decentralized Rural Development Project. (2010). Progress report, January 2005-june 2010. Bamenda.

Grassfield Participatory and Decentralized Rural Development Project. (2008). Report on the elaboration of village development plan in the villages of Ngoketunjia Division, North West Region. Bamenda.

Karlheinz, K., Talis, T., \& Gianluca, B. (2009). Innovation processes in agriculture and rural development; The IN-SIGHT project. In K. Karlheinz, T. Talis, \& P. Sarah (Eds.), Innovation processes in agriculture and rural development (Results of a cross national analysis of the situation in seven countries, research gaps and recommendations) (pp. 7-21). IN-SIGHT $6^{\text {th }}$ framework programme.

Mbafor, N. C. (1998). Self-help efforts and rural development in Cameroon, the case of the Awing community in the North West Province of Cameroon (1986-1996). (Unpublished M.P.A Thesis), Ahmadou Bello University Zaria, Nigeria.

Mbanga, L. A. (2003). Local associations and rural development in Bamunka, Ndop Central Sub Division, North West Province, Cameroon. (Unpublished Maîtrise dissertation), Department of Geography, University of Yaounde I.

Mbanga, L. A. (2005). Community participation in rural development. The case of Ngoketunjia Division, North West Province, Cameroon. (Unpublished DEA dissertation). Department of Geography, University of Yaounde I, 96p.

Mbanga, L. A. (2010). An analysis of Community participation in the rural development process of Ngoketunjia Division, North West Province, Cameroon, A Geographical Approach, (Unpublished Ph.D thesis), Department of Geography, University of Yaounde I, 455p.

Mbunwe, C. (2007). African Development Bank disappointed with Rumpi and GP-DERUDEP. Retrieved from http://www.postnewsline.com/2007/12/adb-disappointe.html.

Menjo B. F. (2003). Globalisation, institutional arrangements and poverty in rural Cameroon. Africa Development, 28(3\&4), 112-141.

Moupou, M., \& Mbanga, L. A. (2008). Désengagement de l'Etat et responses paysannes au Cameroun. Cahier d'Outre Mer, Revue de Géographie de Bordeaux: Milieu rural varia., 61(241-242), 163-183. http://dx.doi.org/10.4000/com.3872 
Ngwa, N. E. (1985). Micro-planning: A departure base for Cameroon's rural uplift. Cameroon Geographic Review, 5(1), 28-34.

Ngwa, N. E. (1987). Rural development strategies: spatial and operational contexts in the Republic of Cameroon. In Revue des Sciences Sociales, Brazzaville.

Shiuh-Shen, C. (2006). Institutional innovations, asymmetric decentralisation and local economic development: A case study of Kunshun in post Mao China. Environment and Planning C; Government and Policy, 25, 269-290.

Umar, A. G. (1992). The role of development finance institutions in the development process of Nigeria. The case of Katsina State Development Company limited (KSDC). (Unpublished MA project), Ahmadou Bello University, Zaria.

Vladislav, V., \& Baum, S. (2008). The institutional economics of rural development: beyond market failure. Journal of central European agriculture, 9(3), 457-462.

Wijayaratna, C. M. (2004). Role of local communities and institutions in integrated rural development. In Wijayaratna (Ed.), Role of Local Communities and Institutions in Integrated Rural Development (pp. 34-62).

\section{Copyrights}

Copyright for this article is retained by the author(s), with first publication rights granted to the journal.

This is an open-access article distributed under the terms and conditions of the Creative Commons Attribution license (http://creativecommons.org/licenses/by/3.0/). 